\title{
Smart Geopolitics, Dangerous Ideas: Energy security, Ideology, and the Challenges of American Policy in the Persian Gulf
}

\section{Diego Pagliarulo}

\section{(2) OpenEdition Journals}

Electronic version

URL: https://journals.openedition.org/ejas/11639

DOI: 10.4000/ejas.11639

ISSN: 1991-9336

\section{Publisher}

European Association for American Studies

\section{Electronic reference}

Diego Pagliarulo, "Smart Geopolitics, Dangerous Ideas: Energy security, Ideology, and the Challenges of American Policy in the Persian Gulf", European journal of American studies [Online], 11-2 | 2016, document 14, Online since 11 August 2016, connection on 08 July 2021. URL: http:// journals.openedition.org/ejas/11639; DOI: https://doi.org/10.4000/ejas.11639

This text was automatically generated on 8 July 2021 .

Creative Commons License 


\title{
Smart Geopolitics, Dangerous Ideas: Energy security, Ideology, and the Challenges of American Policy in the Persian Gulf
}

\author{
Diego Pagliarulo
}

\section{Introduction}

1 Years after the withdrawal of US combat troops from the country, conflict and instability in Iraq still make the headlines in the international media. ${ }^{1}$ Policy-makers in Washington, however, no longer show any particular appetite for large scale military interventions in the Middle East or assertive efforts to reshape the political order in the region. ${ }^{2}$ US policy toward the area is evolving in parallel with the effort to adapt America's global strategy to new political realities and budgetary constraints. "In the next 10 years," wrote former US Secretary of State Hilary Clinton in a seminal policy statement announcing the Obama administration's "pivot" to the Asia-Pacific, "we need to be smart and systematic about where we invest time and energy."3

2A fresh look at US geopolitical priorities and a shift away from Middle Eastern military adventures seems a wise foreign policy approach indeed. Yet, in spite of plans for a "pivot," the Persian Gulf is set to remain a major source of concern for US policymakers. This inescapable trend is demonstrated by the still significant US military presence in the region, by the Obama administration's painstaking efforts to reach a deal aimed at ensuring the peaceful intent of the Iranian nuclear program, and by Washington's military intervention in Iraq in the summer of 2014, in order to sustain a wobbly Baghdad government under heavy pressure from Islamic State - a radical Islamist movement currently in control of large swathes of territory in Iraq and Syria. ${ }^{4}$

3 The challenges that make it so difficult and painful for the US - and for its closest Western allies as well - to work out a policy toward the Gulf region are deep-rooted and 
extremely relevant. On the one hand, as the painful experience of US military intervention in Iraq between 2003 and 2011 has shown, Washington politicians cannot, and should not, be seduced by delusional plans to dominate the region and reorganize it according to their own preferences. ${ }^{5}$ On the other hand, they cannot afford to ignore such a strategically and economically relevant area. This is why, even after the withdrawal of US combat troops from Iraq, American military power and a significant US military presence are still a critical factor in the region's balance of power ${ }^{6}$

4 As this article argues in the following sections, energy security is the most consistent rationale for US and Western engagement in the Persian Gulf. Both as a superpower and as the West's leading security provider, the US has seen its commitment to the stability of the Gulf region and the preservation of access to its oil supplies increase. US Persian Gulf policy, however, has been shaped not only by pure geopolitical considerations, but also by ideological factors concerning America's status and role in international relations. Until recently, this essay observes, US policy toward the Persian Gulf was distorted by the appeal of America's unchallenged military primacy. Confronted with the contradictions and dilemmas of promoting ideals and protecting the national interest, US policy-makers demonstrated a remarkable penchant for instituting policies that overestimated the potential of America's military power as a tool for creating new political realities and favorable outcomes in the region. Such an approach has proved to be extremely costly and frustrating, while the time seems ripe to explore new strategies. Faced with the painful but inescapable challenges coming from the Gulf, the article concludes, the US, and its Western allies, should focus their efforts in the promotion a more inclusive and less militarized regional order.

\section{Energy security and strategy}

5 "One does not need to be a rocket scientist," Gregory Gause points out, "or even a political scientist, to know that oil is why the outside world cares about the Persian Gulf."' More specifically, it seems fair to argue that the US's - and the West's paramount source of concern with regard to the Gulf is to ensure a stable access to, and an uninterrupted flow of, oil supplies from the region. ${ }^{8}$ It is useful to notice, as observed by Robert Keohane, that, along with a stable international monetary system and the provision of open markets for goods, access to oil at stable prices was one of the key pillars of the international order promoted and directed by the US from the end of the Second World War to the early 1970s. ${ }^{9}$

6 The modern oil industry was born in the United States, but by the end of World War Two American leaders became aware that the US domestic production of oil would no longer be able to meet the country's expanding demand for energy. As a consequence, Middle Eastern oil came to be seen in Washington as a critical resource to ensure Western Europe's economic revival ${ }^{10}$ - and by implication as a key pillar of US and Western security. ${ }^{11}$ Seen through that prism, the different "Doctrines" announced by American presidents since the late 1940s appear strikingly informative and consistent. ${ }^{12}$ In March 1947 President Truman first rang the alarm bell by arguing that the political stability in Greece and Turkey and the two countries' inclusion in the Western camp were essential in order to counter the danger of "confusion and disorder" throughout the Middle East. ${ }^{13}$ Ten years later, in January 1957, it was 
President Eisenhower's turn to ask the US Congress to endorse, and provide financial support for, a series of policies aimed at providing the economic and military assistance necessary to ensure the independence and security of "the free nations of the MidEast." ${ }^{14}$ The picture was completed in January 1980, when President Carter famously stated that

7 An attempt by any outside force to gain control of the Persian Gulf region will be regarded as an assault on the vital interests of the United States of America, and such an assault will be repelled by any means necessary, including military force. ${ }^{15}$

8 Along the same lines, a number of examples, present and past, make it possible to discern a critical element in the logic driving Western and US policies, particularly military interventions, in the Southern Mediterranean and the Persian Gulf since 1945: the imperative of ensuring an uninterrupted flow of Middle Eastern oil, and of preventing any "hostile" regime from seizing control of the region's energy resources. ${ }^{16}$ By the 1950s the Suez Canal was the most important gateway through which Persian Gulf oil reached Western Europe. Nasser's decision to nationalize the canal and the fear of an interruption in the oil flows was a key factor underpinning the awkward and inglorious Anglo-French military intervention against Egypt in collusion with Israel in late $1956 .{ }^{17}$ Analogous considerations, combined with humanitarian concerns and calculations relating to domestic politics, were at play in 2011 - fifty-five years later as the same two powers led NATO's military intervention in Libya in support of insurgents fighting to topple the Qaddafi regime. Libya's "sweet" crude oil could not be easily replaced in the production of gasoline by many European refineries. ${ }^{18}$ US leaders seriously considered the use of military force as a possible response to the embargo announced by the Organization of Arab Petroleum Exporting Countries as an apparent "weapon" to pressure Western countries into abandoning their support for Israel at the time of the October War of $1973 .{ }^{19}$ Washington did resort to military intervention during the last phases of the Iran-Iraq War, when the Reagan administration decided to re-flag oil tankers from Kuwait and other Gulf Arab monarchies and to deploy US warships in the Gulf in order to counter the threat posed by Iran to the free passage of Persian Gulf oil through the Strait of Hormuz. ${ }^{20}$ An analogous threat to the flow of oil through the Strait became a major source of concern in 2012 due to the confrontation between the West and Iran revolving around the Teheran regime's nuclear program. ${ }^{21}$ In fact, the specter of a disruptive military confrontation cast a dark shadow throughout the delicate negotiating process that led to the July 2015 nuclear agreement between Iran, the US, and other major powers. ${ }^{22}$

9 America's military involvement in the Middle East, particularly in the Persian Gulf, is thus consistent with a well-established pattern of Western security policy, and appears to be the expression of a grand strategy aimed not merely at ensuring the energy needs of the US, but rather at reducing the risk of instability in the global oil market - since global oil shocks would inevitably have negative effects on fuel prices at the pump in the US. ${ }^{23}$

\section{Ideology and American grand strategy}

10Geopolitics and energy security have not been the only factors driving US policy toward the Persian Gulf. America's quest for the stability and security of world energy supplies has been strongly influenced, and often distorted, by ideological 
considerations concerning the nature of US power and America's role in international relations.

11During the Cold War, US global strategy was informed by the imperative of containing communism. Hence, American policy toward the Persian Gulf was conceived and implemented within the wider framework of countering the spread of communism and Soviet influence in the Middle East. ${ }^{24}$ It seems fair, in retrospect, to argue that US leaders tended to overestimate the aggressive designs of their Kremlin counterparts concerning the Gulf area while they failed to appreciate the development of political and strategic challenges from within the region, such as the rise of Islamist extremism. ${ }^{25}$ However, it is important to acknowledge that the perception of the Soviet threat was not unjustified. By the end of the 1970s, Moscow's rising activism in the Horn of Africa and the Soviet invasion of Afghanistan dramatically increased the level of concern among US leaders about the security of the Persian Gulf. ${ }^{26}$ As noted above, it is indeed from the early 1980s onward that US military involvement in the region began to rise, first with the creation of a Rapid Reaction Force by the Carter administration, and then with the establishment by the Reagan administration of the Central Command (CENTCOM) - a new unified military command tasked with the planning of military operations in the region stretching from the Middle East to Southwest Asia. ${ }^{27}$

12The collapse of communism and the end of the Soviet threat have imposed a critical reassessment of US grand strategy. Confronted with the challenges of the postCold War era, American officials and opinion makers on both sides of the political spectrum found inspiration in the traditional US commitment to the promotion of a liberal and democratic world order. ${ }^{28} \mathrm{An}$ important legacy of the Cold War experience, however, was the reality of America's massive and unchallenged military power. ${ }^{29}$ It seems indeed fair to argue that the very preservation of such an unchallenged military primacy became an objective per se according to a great many American policy-makers and foreign policy circles. ${ }^{30}$ As suggested by Andrew Bacevich, "at the end of the Cold War Americans said yes to military power." ${ }^{31}$ Post-Cold War US leaders promoted different worldviews and adopted different foreign policy approaches - as well as different plans to revive the American economy and society - but it seems fair to argue that all US presidents and their national security teams were seduced by the idea that as the world's only superpower, the United States enjoys an unchallenged position of material and moral superiority. By implication, leaders in Washington tended to define their foreign policy objectives independently from the specific dynamics of the conflicts in which the US decided to get involved, and almost without paying attention to the interests and the priorities of other great powers or regional actors. Confronted with the contradictions and dilemmas of promoting ideals and protecting the national interest, US policy-makers demonstrated a remarkable penchant for instituting policies that overestimated the potential of America's military power as a tool for creating new political realities and favorable balances of power overseas..$^{32}$ US policy towards the Gulf somewhat embodies that delusional trend - Washington's military involvement in the region progressively increased since the 1980s, reaching its apex with the Iraq War of $2003 . .^{33}$

13The enormous human and economic costs of US military interventions in Iraq and Afghanistan, combined with the financial crisis of 2008, appear to have significantly moderated this historical trend. Since taking office in 2009, the Obama administration 
has been remarkably less inclined than its predecessors to put boots on the ground overseas, although it is not entirely clear whether that depends on a profound reassessment of America's role in the world or rather by budgetary constraints and the recent memory of military quagmires. ${ }^{34} \mathrm{The}$ Obama administration took office after years of consuming overseas military commitments and in the midst of the worst economic crisis since 1929. Inevitably, the administration's main efforts have concentrated on avoiding economic collapse and promoting reform at home. During the first term, the most pressing foreign policy issue was in fact the need to cope with the challenges inherited by the past administration. ${ }^{35} \mathrm{As}$ a newly elected president, Obama articulated an appealing foreign policy outlook, which called for a conception of US global leadership based on institutions and the international rule of law, multilateralism and diplomacy rather than outright military power. This cautious and diplomacy-savvy approach appears to have allowed the US to manage international crises without the need to resort to new, massive, and open-ended overseas military commitments, although not all of the high expectations originally raised by Obama have been turned into actual policies. ${ }^{36}$ In practical terms, as reported by James Mann, the Obama administration's key foreign policy concept was "rebalancing," the idea that it was necessary for the US to refrain from military adventures overseas and, in general, to adopt a more pragmatic attitude on the international stage. ${ }^{37}$ However, the increasing resort to air power - particularly drone strikes - and special forces for counter-terrorism operations, as well as the critical US role in the early phases of NATO's air campaign in Libya, suggest that after all Obama and his foreign policy staff are not so shy about using force. ${ }^{38} \mathrm{As}$ the end of the second term approaches, the foreign policy approach of the Obama administration has evolved toward a doctrine of "engagement" aimed at improving relations with countries - such as Iran, Cuba, and Myanmar - that have been at odds with the US but appear ready to sit at the negotiating table. ${ }^{39}$ In the ultimate analysis, however, the Obama administration's foreign policy is still in the making, and it is impossible to assess what its long term legacy will be.

14 What seems fair to argue so far is that ideology and perception have encouraged the militarization of US policy toward the Persian Gulf. That, in turn, has contributed to worsen a number of negative regional trends - particularly the growing polarization and radicalization of local political regimes. The Gulf area is a jigsaw of ethnic and sectarian identities that overlap with states whose borders and political institutions are relatively recent and often weakly legitimized in the eyes of the local populations. As a consequence, since the emergence of the Gulf as a "regional security complex," ${ }^{40}$ local regimes, especially the most powerful and ambitious among them - Iran, Iraq and Saudi Arabia - look at each other with suspicion and alarm. The rise of regional powers is perceived by the other regimes in the area as a threat to their own domestic stability, and such a perception is often confirmed by the foreign policies actually pursued - the most blatant example being perhaps the rivalry between Saddam's Iraq and Khomeini's Iran. Furthermore, such a dynamic has been worsened by volatile but increasing oil revenues, which have distorted the pattern of economic and social development of the Gulf countries and placed the region's governments in a position to build disproportionate and pervasive national security apparatuses. ${ }^{41}$ 


\section{The United States and the Persian Gulf: the paradoxical implications of the clash between geopolitics and delusions from the Cold War to the War on Terror}

15 Seen from the point of view of the interplay of geopolitical necessities and ideological imperatives, the story of American involvement in Persian Gulf politics is the story of a long series of unrealistic expectations, lost opportunities, and dysfunctional outcomes.

\subsection{Geopolitics and ideology during the Cold War}

16America's involvement in the region has begun to expand dramatically since the early 1970s, in the aftermath of Britain's withdrawal from "East of Suez." By that time, however, for a variety of reasons Washington was by no means in an ideal position to replace London as the guarantor of the region's stability and balance of power. First, the war in Vietnam had severely eroded Congressional and popular support for military engagements overseas. Second, the protracted military effort in Southeast Asia had significantly contributed to the financial distress that had forced the Nixon administration to suspend and eventually abandon the gold-exchange standard through which Washington had guaranteed international monetary stability since the end of the Second World War. Third, the oil shock of 1973 had put an additional burden on the challenge of reviving the economies of the US and the rest of the industrialized countries of the West. It was within such a daunting framework that President Nixon formulated his doctrine, according to which America's interests overseas would increasingly be protected by relying on regional partners. ${ }^{42}$ As for the Persian Gulf, the new American strategic outlook translated into the "Twin Pillar" approach, according to which Washington would support - particularly through the sale of larger and larger amounts of increasingly sophisticated weapons - the rise of Saudi Arabia and, even more important, of Iran. The two countries were thus supposed to serve as the guarantors of a regional balance of power favorable to American interests - in spite of the fact that the regimes in Riyadh and Teheran shared very little in terms of ambitions and strategic priorities. ${ }^{43}$

17The Twin Pillars approach was shattered in 1979 by the Iranian Revolution. As the new regime led by ayatollah Khomeini was still consolidating, the seizure of the US embassy in Teheran and the subsequent diplomatic crisis dramatically poisoned Washington's relations with Teheran. Iran, once perceived as the US's most powerful and reliable partner in the Gulf, was now a nemesis in the minds of Americans and their leaders. ${ }^{4}$

18That new state of mind strongly informed Washington's attitude toward the war between Iran and Iraq. The Iraqi aggression, incompetently planned and ineffectively implemented ${ }^{45}$ in September 1980 under the watch of Baghdad strongman Saddam Hussein - at the time an unlikely client of the Soviet Union - came to be seen by strategists in Washington as a sort of opportunity to redress the Gulf's balance of power according to the American interest of preventing a hostile power from achieving hegemony in the region. 
19Thus, a combination of emotions and geopolitical opportunism was at the foundations of the troubled and awkward relationship between the Unites States and Iraq in the 1980s - a relationship tainted by the Iran-Contra scandal and the bombing by an Iraqi fighter jet of a US warship patrolling the Persian Gulf waters, but constantly corroborated by US economic support and intelligence assistance reciprocated by gestures of moderation on the part of Saddam Hussein concerning Iraq's role in the Middle East.

20As bluntly revealed by the Iraqi invasion and seizure of Kuwait in August 1990, however, Saddam's agenda was rather at odds with the wishes of Washington politicians. Within a few hours the Baghdad regime had ended up in possession of a new piece of very valuable real estate - according to estimates widely publicized in the aftermath of the invasion, control of Kuwait ensured direct control of $20 \%$ of the world oil reserves and placed Iraq in a position to threaten Saudi Arabia, which possessed an additional $20 \%{ }^{46}$ Iraq's aggression changed the White House's perception of Saddam, from someone with whom it was possible to "do business" to a "madman" aiming to establish an anti-American hegemony over the Gulf region - a modern version of Adolf Hitler, as Bush père often suggested in public, to the dismay of some of his closest and most pragmatic advisers. ${ }^{47}$

\subsection{Geopolitics and ideology in the post-Cold War era}

21The Gulf crisis of 1990-1991 was the first crisis of the post-Cold War era, and, in addition to being essential to the understanding of the foundations of the current US predicament in the Gulf, is emblematic of the dysfunctional combination of geopolitical thinking and ideological delusions that have marked the foreign policy of the US as the sole superpower. The first Bush administration publicly articulated its policy toward the crisis as an effort to restore international law by resisting Iraq's blatant aggression and occupation and liberating Kuwait - a sort of international police operation led by the US under the aegis of the UN. US strategy, however, was geared at achieving additional objectives which were much more at variance with the orientations of the international community as a whole. As seen from the White House, the outcome of the crisis should have been a new balance of power in the Gulf. On the one hand, Iraq's military power should be downgraded, and Iraq should be deprived of any nonconventional military capability - in order not to represent a threat to the US-friendly, oil-exporting Gulf Arab monarchies. On the other hand, Iraq should stay strong enough to serve as a bulwark against Iranian influence in the region. ${ }^{48} \mathrm{~A}$ critical component of this post-crisis scenario was an Iraqi leadership strong enough to keep the country united but willing to reorient its foreign policy in favor of the US - what was needed, in other words, was a sort of replica of the idealized perception of the pre-August 1990 Baghdad regime. It is open to question whether such an optimistic outcome was a realistic objective. Yet, as recalled by James Baker, George H.W. Bush's Secretary of State, that conviction was particularly popular within the administration - the US military machine was expected to defeat Saddam so blatantly that someone within his own regime, possibly someone from the military, would rise against him, as suggested by the president himself during the Gulf War. ${ }^{49}$ Thus, as argued by Gideon Rose, "the administration decided that hope could indeed be a plan." Kuwait would be liberated through a massive military intervention. In the process, Saddam's power base would be 
destroyed, and the US would "wait" for his regime to collapse, as recalled by Bush's National Security Adviser Brent Scowcroft. ${ }^{50}$

22The process through which the George H.W. Bush administration articulated its policy and won UN Security Council approval for the implementation of a military solution to the Gulf crisis was a masterpiece in diplomacy, and the swift and amazing success of the US led military campaign against Iraq put the US in a position of unquestioned authority within the international community. In the aftermath of the liberation of Kuwait it became clear that the first Bush administration was endowed with enormous political capital that could be invested not only in the pursuit of a more stable and inclusive security arrangement in the Gulf, but also in the advancement toward the solution of many of the Middle East's most intractable conflicts, such as the Arab-Israeli conflict. The administration's critical priority, however, was to bring Iraq "back into the family of nations," ${ }^{51}$ which, in retrospect, clearly meant waiting for the optimist scenario imagined in the run up to operation Desert Storm to unfold. As it became clear that Saddam would not be overthrown in the short term, however, Bush and his advisers were forced to imagine and gather international support around continuous adjustments to their plan. The administration declared its readiness not to violate Iraq's sovereignty or integrity, yet it promoted an intrusive system of international inspections to monitor the dismantlement of the Baghdad regime's nonconventional arsenal. Furthermore, it refused to normalize relations with Iraq and pushed for the continuation of the UN sanctions regime that had been put in place in the aftermath of the Iraq invasion of Kuwait as long as Saddam Hussein remained in power. The White House thus invested most of its political and diplomatic capital on an effort to transform Iraq according to its wishes, at the expenses of exploiting in full the opportunities to negotiate a comprehensive settlement in the Middle East. As a paradoxical result, by the time the George H.W. Bush administration left office, in January 1993, Saddam was still in power in Iraq, the Middle East remained an unstable region, a large and visible US military presence was required to "contain" the Baghdad regime and ensure the stability of the Gulf region, and yet the restoration of Iraq as a major oil producer was postponed indefinitely because of the sanctions regime.

23Bill Clinton and his staff entered the White House with a worldview and a set of priorities rather different from those of their predecessors, yet as far as the Persian Gulf was concerned the new administration didn't question the policy it had inherited. Quite the contrary, it decided to expand its reach, by turning it into a "Dual Containment" approach, intended to use American power to prevent both Iraq and Iran from threatening the stability of the Persian Gulf and to ensure the free flow of oil in the area..$^{52}$ No one within the Beltway apparently noted that, having been a victim of Saddam's aggression, Iran had been promoting the idea of regime change in Iraq since the 1980 s. $^{53}$

24Thus, in the 1990s US policy toward the Gulf became increasingly based on the assumption of American primacy and on the idea that the US had the power and the authority to marginalize those "rogue regimes" that did not fit into Washington's vision of world order. As part of the Dual Containment strategy, Iraq was kept under a severe regime of economic sanctions and constant military pressure - including recurrent US and allied airstrikes within the country's territory - with dramatic implications for the Iraqi population. From the mid-1990s onward, moreover, a sanctions regime was established against Iran as well, in spite of the rise to power of an 
Iranian leadership deeply interested in domestic reform and the improvement of relations between the Teheran regime and the rest of the world. ${ }^{54}$ Once again, the paradoxical result was that not only Saddam Hussein remained in power in Iraq, but now both Iran and Iraq - OPEC's most prominent oil producers after Saudi Arabia were denied full access to the global oil market.

\subsection{Geopolitics, ideology, and the War on Terror}

25By the late 1990s the policy of containment toward the Gulf had become increasingly frustrating. It was definitely shattered by the tragedy of 9/11. Al-Qaida's appalling and unjustifiable terrorist attacks in New York and Washington D.C. were met by virtually unanimous condemnation on the part of the international community. The American leadership was in a position to assemble through a shrewd use of diplomacy a strong and comprehensive international coalition - as the George H.W. Bush administration had done a decade earlier - and use US power and authority to counter the challenge of terrorism and create a more stable and sustainable order in the Middle East. ${ }^{55}$ The connection between al-Qaida and the Sunni extremist Taliban regime in Afghanistan, moreover, provided a critical opportunity to improve relations between the US and Iran in the Gulf - throughout 1990s Iran, along with other powers such as India and Russia, had been an active supporter of the anti-Taliban Northern Alliance. (In contrast, the Taliban had been receiving substantial logistical and military backing from the Pakistani intelligence services as well as economic support coming from Saudi Arabia - Pakistan and Saudi Arabia being supposedly two of America's closest partners in the region. $)^{56}$

$26 \mathrm{By}$ the time the tragedy of 9/11 unfolded there was indeed a Bush in the White House. He was the son of that President Bush under whose watch the Cold War had ended peacefully and a large coalition led by the US under the aegis of the UN had won the Gulf War, and his administration was packed with veterans of his father's team. However, diplomatists were conspicuously absent from the staff of Bush fils. As a result, the George W. Bush administration decided to meet the challenge posed by $9 / 11$ by embracing in full, and bringing to its extreme consequences, the grand strategy based on American primacy, and opted for a policy of unilateral US military intervention against the Taliban in Afghanistan. In addition, the unilateral pursuit of the "Global War on Terror" launched by the second President Bush, became an opportunity to settle the long-standing conflict between the US and Iraq on Washington terms, by invading the country and overthrowing the regime of Saddam Hussein - first on the basis of an unlikely connection between the Baghdad regime and Osama bin Laden's terrorist network, which appeared ungrounded even before the invasion, and then on the basis of very weak evidence concerning Iraq's covert pursuit of non conventional weapons, which turned out to be false in the aftermath of the invasion. ${ }^{57}$

27George W. Bush's "War on Terror" amplified the effects of the dysfunctional approach endorsed by the American leadership since the end of the Cold War. First of all, soon after regime change, the US found itself struck in the effort to quell bloody insurgencies both in Afghanistan and Iraq, two countries highly heterogeneous on both the ethnic and the sectarian level. Both occupations turned into quagmires, with negative implications for America's global military position and the US treasury. Second, applying the democratic principle to the political reconstruction of Iraq 
implied a redistribution of power within the country in favor of the demographically predominant Shia community - which had been historically deprived of political influence. Thus, a prominent consequence of the US policy of regime change was to open the door to Iran's influence in Iraq. Finally, US military interventions in Afghanistan and Iraq had the unintended consequence of freeing Iran of two critical strategic threats - the Sunni extremist Taliban in the East and Saddam Hussein's regime in the West. Seen from Teheran, such an improvement made the case for pursuing a nuclear program even more compelling: a nuclear deterrent would not only ensure the Teheran regime from external threats but also consolidate Iran's power and influence in the Gulf region. ${ }^{58}$

280verall, the George W. Bush administration's "Global War on Terror," far from resolving once and for all the problems of the Persian Gulf, exacerbated them. As Bush fils prepared to leave office in January 2009, the most pressing challenges concerning the Gulf were in fact how to exit the Iraqi quagmire without seeing the country fall back into civil war, or even collapse, ${ }^{59}$ and how to deal with the challenge of Iran's nuclear program - two issues that were to say the least latent prior to, and even in the immediate aftermath of, 9/11. Both developments had significant negative repercussions in terms of US and global energy security. The distribution of oil revenues was a key source of internal conflict in post-Saddam Iraq, and the civil war that followed regime change shattered the dreams of a smooth revival of the Iraqi oil industry. ${ }^{60}$ Meanwhile, the mounting tension between the US and Iran and the risk of military confrontation revolving around the Iranian nuclear program restricted Iran's access to the global energy market and contributed to the volatility of prices. ${ }^{61}$

\section{Obama's "rebalancing" and the US "energy revolution": smart geopolitics or dangerous ideas?}

29The withdrawal of US combat troops from Iraq in December 2011 appears to have put an end - at lest for a while - to the era of American military adventurism in the Middle East. ${ }^{62}$ In fact, since 2011, the political landscape in the Middle East has been shaken by a wave of uprisings that have led, with varying degrees of violence, to the fall of some of the most impervious regimes in the region - a process that has become commonly known as the "Arab Spring." The actual dynamics that are generating upheaval vary significantly from country to country, but it seems fair to observe that the main drivers of change are long lasting domestic economic and social tensions, rather than the designs of foreign powers. ${ }^{63}$ With the notable exception of Bahrain, the oil rich Persian Gulf Arab monarchies have been remarkably more stable than the rest of the Arab world, but the Gulf states are nonetheless deeply involved in the varied but interconnected processes of political change that are transforming the Middle East. ${ }^{64}$

30The "Obamians" appear to have tentatively begun to explore new policy approaches concerning the Gulf - such as withdrawing combat troops from Iraq and making the US military presence in the region more discrete, or working out a diplomatic solution to the Iranian nuclear issue - but they're still far from achieving substantial and long-lasting results. In their quest for a more "balanced" policy toward the region, the president and his advisers should avoid the flawed delusional attitude oscillating between dreams of outright dominance and dreams of indirect control that characterized past policy initiatives. In this era of "rebalancing," moreover, they 
should also be careful not to fall prey to fresh delusional attitudes, such as the idea of a disengagement from the region. ${ }^{65}$ This option has been made increasingly appealing by the recent "energy revolution" that is boosting the US oil and gas industry, but a close examination suggests that the implications of the new developments in the energy sector for US and Western energy security may be limited.

31The Persian Gulf has proved to be a source of headaches for American leaders. Since the most consistent rationale for US and Western engagement in such a challenging area has been energy security, it seems legitimate to assess whether new developments in the global energy sector may create the conditions for a disengagement on the part of Washington and its Western allies. In fact, recent improvements in drilling and extraction technology have made unconventional hydrocarbon resources increasingly accessible. These breakthroughs have largely expanded the exploitable reserves of oil and gas in the US, and have significantly revived the US oil and gas industry. US oil production has been increasing since 2012, and according to several estimates the US could dramatically reduce hydrocarbons imports and get close to energy self-sufficiency in the coming decades. ${ }^{66}$ Such a new development has indeed fostered speculation about the geopolitical implications of the possible US "energy independence." Authoritative commentators argue that newly exploitable non-conventional oil reserves will reduce the geopolitical clout of a number of current major oil producers that tend to be at odds with the US, and that an America less addicted to foreign oil may no longer need to be so involved in intractable issues such as Persian Gulf politics. ${ }^{67}$

32 The recent "energy revolution" in the US will make the US economy more competitive and will have very positive implications for the US trade balance. ${ }^{68}$ In addition, increasing oil and gas production in the US contributes to the expansion of supply in the global energy markets, so it is likely to moderate global energy price increases and have a positive impact for all energy consuming countries. ${ }^{69}$ It seems wise, however, to be cautious about its implications for American foreign policy. ${ }^{70} \mathrm{As}$ noted by Daniel Yergin, "Only one oil market exists," that is, the global oil market. The price of oil is a function of demand and supply dynamics that operate on a global scale, and, as a consequence, instability in the global oil market has, and will continue to have, negative implications in term of the price of fuel at the pump. ${ }^{71}$ In the ultimate analysis, oil remains the most important energy resource, and the Persian Gulf, with its massive reserves and very low extraction costs, is, and will remain for quite some time, the greatest and strategically most important oil producing region in the world. ${ }^{72}$ That is why what happens in the region still matters for the security of the US and its closest allies, and there are very few reasons to believe that politicians in Washington will be in a position to neglect the security challenges coming from the area. ${ }^{73}$

\section{The case for pragmatism}

33Sadly, besides being a vitally important oil producing region, the Gulf is also an area of instability and inter-state tensions with persistent threats - such as terrorism and nuclear proliferation - contributing to the volatility of global oil prices. The US has played - and continues to play as these pages are written - a most prominent role in the Persian Gulf. Such a role derives from America's status as the greatest military power in the world as well as from its interest in ensuring a stable and abundant supply 
of oil in global markets. As shown by this essay, however, the interplay of strategic, economic, and ideological factors that characterizes American policy toward the region has produced an unsustainable equilibrium that challenges the very rationale of US involvement - global energy security.

34It is important to acknowledge that US policy toward the Persian Gulf has suffered from a lack of realism on the part of American leaders. Washington strategists have too often been ready to believe that they could count on compliant local clients, or that they could opportunistically exploit regional rivalries, or that they could manipulate the region's balance of power by resorting to military power in order to protect their interests without the need to make compromises. Such an approach has largely failed. Massive US military intervention often exacerbated conflicts and instability, and, contrary to the expectations of so many politicians and armchair strategists, it led to restrictions in free flow of oil from the region. Furthermore, although US policy became more and more unilateral, the implications of American actions remained multilateral and ramified - and frequently had the unintended consequence of improving the strategic position of powers, such as Iran, that challenge the US role and presence in the region.

35As observed by Mahmoud El-Gamal and Amy Myers Jaffe, instability in the Persian Gulf seems to have created a sort of vicious circle with cyclical implications on the price of oil in global markets: "petrodollar flows create a military buildup that escalates the risk of conflict, which in turn increases the petrodollar flows and feeds more military buildups and potential conflict, and so on." 74 Because of its approach characterized by massive military involvement but lack of political realism, the US has become part of this vicious circle.

36It seems reasonable to maintain that only the political will of the local populations and their leaders can interrupt this detrimental dynamic. As the story of American involvement in the Gulf suggests, no external intervention, and especially no military intervention, should be considered capable of changing "hearts and minds" on its own. Since some form of engagement between the region and the rest of the world is inescapable, however, a more pragmatic assessment of the interests at stake and the means to protect them on the part of leaders in Washington and in allied capitals could at least reduce the effects of the vicious circle and contribute to create the conditions for improving stability and security in the area.

3TThe paramount priority for the US, and for the rest of the international community, concerning the Persian Gulf, is to promote the emergence of a more stable and inclusive equilibrium in the area, in order to minimize the effects of geopolitical risk on the global energy markets and reduce the incentives for local regimes to invest their wealth in arms and national security apparatuses. Thus, in the short term, efforts should concentrate on fostering a modus vivendi among the region's greatest powers and encourage the mutual recognition of the regimes in place in the area. From this point of view, the July 2015 Iran nuclear deal - which sets limits on, and increases international supervision over, Tehran's nuclear program in exchange for the gradual lift of international economic sanctions against Iran - appears to be a step in the right direction and possibly a game changer in the geopolitics of the Persian Gulf. ${ }^{75}$ Nuclear proliferation should always be a source of concern for policymakers, but coercive measures such as sanctions and military strikes are not sustainable long term solutions to that challenge because they fail to address the critical political issues that prompt a 
country to engage in the development of a nuclear deterrent - such as the desire to hedge against a real or perceived existential threat. ${ }^{76}$ The eventual normalization of relations between Iran and the US is far from certain, and the deal has given rise to political squabbles in the US Congress and to uncertainty and resentment among longstanding US allies in the region. ${ }^{77}$ Given Iran's potential geopolitical clout, its influence over the Shia communities in the Arab world and the close relations of the Iranian government with the Assad regime in Syria and militant groups such as Lebanon's Hezbollah, these concerns should not be overlooked. Iran's economic and political revival, however, appears to be a critical but inescapable challenge for the stability of the Persian Gulf. Moreover, the country's new leadership appears to be much less inclined to sacrifice Iranian economic revival on the altar of confrontation with the US. ${ }^{78}$ Hence, political negotiations, no matter how difficult or embarrassing, must have priority over costly and potentially counterproductive coercive measures. Considering the history of the region, Iran's desire for greater security and a greater role on the regional level is not an unreasonable aspiration, as long as the Tehran leadership understands that Iran should refrain from seeking regional hegemony. As a matter of fact, once a more pragmatic attitude is embraced, it turns out that Iran and the West do have a number of very important interests in common - they want a stable Iraq at peace with its neighbors, they do not want Afghanistan to be dominated by the Taliban, and Iran is the shortest and cheapest route for Caspian oil and gas to reach global markets. ${ }^{79}$ Building upon those shared interests would not only minimize the risks of nuclear proliferation in the Gulf, but also have positive political and economic implications for the region and beyond.

$38 \mathrm{~A}$ critical long term challenge in the framing of a more stable and inclusive regional order in the Gulf is the need to cope with the imbalance between the oilproducing Arab monarchies and their more powerful neighbors, Iran and Iraq. Until recently, the policy of choice to deal with this problem was a combination of increasing arms sales and increasing direct US military presence in the region. Such an approach has proved to be extremely costly and frustrating, and the time seems ripe to seriously explore new policy approaches. In fact, a careful assessment of the global strategic and economic relevance of the Persian Gulf suggests that not only the US and its Western allies, but also emerging Asian powers, particularly China, have an interest in stability, economic opportunities, and access to energy resources in the area. ${ }^{80}$ Strategists in Washington and allied capitals should not panic over greater involvement of these powers in the region, but rather encourage them to invest constructively their increasing economic and political influence in the promotion of a more cooperative and inclusive regional order. ${ }^{81}$ Enthusiast supporters of American primacy might denounce such an approach as a "declinist" attitude; other, more pragmatic observers and practitioners might welcome it as a useful recognition of the limits of power and a smart way to reduce costly military commitments while fostering great power cooperation on the global level.

\section{Conclusion}

39The political evolution of the Gulf - and for that matter of the whole Middle East is something that policymakers in Washington can neither ignore nor control. Hence, the US and its Western allies should not strive to reshape or control the geopolitics of 
the Persian Gulf - both approaches are unfeasible. The idea of disengagement from the region, moreover, appears delusional even when the implications of the unconventional energy revolution are held into account. Rather, America and its allies should focus their engagement on promoting better mutual understanding among regional actors and greater cooperation among the regional and global powers that have a stake in the stability of such a strategically and economically important area. Short of such a framework of coordination and mutual understanding, the resort to US and allied military power should be considered not only ineffective, but even counterproductive. In the long run a less militarized, more stable, and more inclusive regional framework could even become the basis for promoting in the Gulf some of the developments that America's military adventures have failed to achieve, such as the spread of democracy and respect for human rights.

\section{NOTES}

1. Joseph Logan, “Last U.S. Troops leave Iraq, ending war", Reuters, December 18, 2011, http:// www.reuters.com/article/2011/12/18/us-iraq-withdrawal-idUSTRE7BH03320111218 ; Dominic Evans, "A country in peril - Iraq's struggle to hold together," Reuters, July 27, 2014, http:// www.reuters.com/article/2014/07/27/us-iraq-security-future-idUSKBN0FW06D20140727.

2. "The decline of deterrence," The Economist, May $3^{\text {rd }}, 2014$.

3. Hilary Clinton, “America's Pacific Century," Foreign Policy, October 11, 2011, http:// www.foreignpolicy.com/articles/2011/10/11/americas_pacific_century .

4. Thom Shanker and Steven Lee Myers, "U.S. Planning Troop Buildup in Gulf Afer Exit from Iraq", The New York Times, October 29, 2011, A1, http://www.nytimes.com/2011/10/30/world/ middleeast/united-states-plans-post-iraq-troopincrease-in-persian-gulf.html?_r=1\&ref=globalhome ; Thom Shanker, Eric Scmitt, and David E. Sanger, "U.S. Adds Forces in Persian Gulf, a Signal to Iran", The New York Times, July 3, 2012, A1, http://www.nytimes.com/2012/07/03/ world/middleeast/us-adds-forces-in-persian-gulf-a-signal-to-iran.html?_r=0 ; Raheem Salman and Isabel Coles, "U.S. bombs Islamic State after Obama call to prevent Iraq 'genocide'," Reuters, August 8, 2014, $\quad$ http://www.reuters.com/article/2014/08/08/us-iraq-securityidUSKBNOG808J20140808 .

5. George Packer, The Assassins' Gate. America in Iraq (New York: Farrar, Straus and Giroux, 2006); Thomas E. Ricks, Fiasco. The American Military Adventure in Iraq (New York: Penguin, 2007); Gilles Kepel, Fitna. Guerre au cœur de l'islam (Paris: Gallimard, 2004).

6. "The decline of deterrence," The Economist, May $3^{\text {rd }}, 2014$, http://www.economist.com/news/ united-states/21601538-america-no-longer-alarming-its-foes-or-reassuring-its-friendsdecline\#sthash.aIoJwGoB.dpbs ;

7. F. Gregory Gause, III, The International Relations of the Persian Gulf (Cambridge: Cambridge University Press, 2009), 245.

8. Jean-Marie Chevalier, Les grandes btailles de l'énergie (Paris: Gallimard, 2004), 306. Ehtan Kapstein, The Insecure Alliance. Energy Crises and Western Politics since 1944 (New York and Oxford: Oxford University Press, 1990), viii, 202.

9. Robert O. Keohane, After Hegemony. Cooperation and Discord in the World Political Economy [2 $2^{\text {nd }}$ Edition] (Princeton and Oxford: Princeton University Press, 2005), 139. 
10. Leonardo Maugeri, The Age of Oil. The Mythology, History, and Future of the World's Most Controversial Resource (Guilford: The Lyons Press, 2008), 51-61; Kapstein, Insecure Alliance, 47, 62. 11. Daniel Yergin, The Prize. The Epic Quest for Oil, Money \& Power (New York: The Free Press, 2009), 409; Michael A. Palmer, Guardians of the Gulf. A History of America's Expanding Role in the Persian Gulf, 1833-1992 (New York: The Free Press, 1992), 20-51; David S. Painter, "Oil, resources, and the Cold War, 1945-1962," in Melvin P. Leffler and Odd Arne Westad, eds., The Cambridge History of the Cold War, Vol. 1, Origins (Cambridge: Cambridge University Press, 2010), 486-507.

12. Michale T. Klare, Blood and Oil. The Danger and Consequences of America's Growing Dependency on Imported Petroleum (New York: Holt, 2005), 37-50.

13. Harry S. Truman: "Special Message to the Congress on Greece and Turkey: The Truman Doctrine," March 12, 1947, Gerhard Peters and John T. Woolley, The American Presidency Project [online]. Santa Barbara, CA. http://www.presidency.ucsb.edu/ws/?pid=12846 .

14. Dwight D. Eisenhower, "Special Message to the Congress on the Situation in the Middle East," January 5, 1957, Woolley and Peters, The American Presidency Project,http:// www.presidency.ucsb.edu/ws/?pid=11007

15. James E. Carter, "The State of the Union Address Delivered Before a Joint Session of the Congress" January 23, 1980, Woolley and Peters, The American Presidency Project, http:// www.presidency.ucsb.edu/ws/?pid=33079.

16. Michael T. Klare, "Oil, Iraq and American Foreign Policy: The Continued Salience of the Carter Doctrine”, International Journal, 62, No. 1 (Winter 2006/2007): 31-42.

17. Maugeri, Age of Oil, 95; Yergin, Prize, 461-480; Kapstein, Insecure Alliance, 103-105. It seems interesting to note the continuing relevance of the Suez Canal as a key oil choke point: between 2011 and 2013, political instability in Egypt raised investors' concerns about the risk of interruptions in the passage of oil tankers through he canal, with direct consequences on oil prices. "Protest and the pump", The Economist, February $5^{\text {th }}, 2011,67$; Konstantin Rozhnov, "WTI Rises Above $\$ 100$ on Drop in U.S. Stockpiles, Egypt Unrest," Bloomberg, July 3, 2013, http:// www.bloomberg.com/news/2013-07-03/wti-crude-climbs-above-100-on-egypt-unrest-u-sstockpiles.html.

18. Clifford Krauss, "Why the disruption of Libyan Oil Has Led to a Price Spike", The New York Times, February 24, 2011, B1. Daniel Yergin, The Quest. Energy, Security, and the Remaking of the Modern World (New York: Penguin, 2012), 294; Paul Taylor, “The West's unwanted war in Libya," Reuters, April 1, 2011, http://www.reuters.com/article/2011/04/01/us-libya-decisionsidUSTRE73011H20110401 ; Michael Hastings, "Inside Obama's War Room," Rolling Stone, October 27, 2011, http://www.rollingstone.com/politics/news/inside-obamas-war-room-20111013.

19. Douglas Little, American Orientalism. The United States and the Middle East Since 1945 [Third Edition] (Chapel Hill: University of North Carolina Press, 2008), 243; Palmer, Guardians, 99-100. By the time the "embargo" was lifted, none of the demands concerning the Arab-Israeli conflict had meaningfully been met. Moreover, as a matter of fact, production cuts didn't appear to penalize the industrial countries singled out as the targets of the embargo. It seems more correct to argue that the most significant consequence of the crisis of 1973 was not greater geopolitical clout for the Arab countries, but rather a greater capacity of OPEC countries to coordinate production in order to influence the global supply of oil. M.A. Adelman, Genie Out of the Bottle. World Oil Since 1970 (Cambridge, MA: The MIT Press, 1995), 112-117; Yergin, Prize, 585-591, 595-614.

20. Palmer, Guardians, 120-127.

21. Ramin Mostafavi, "Iran test-fires missiles in Gulf exercise", Reuters, January 2, 2012, http:// www.reuters.com/article/2012/01/02/us-iran-missile-idUSTRE80007E20120102 .

22. Kenneth M. Pollack, Unthinkable. Iran, the Bomb, and American Strategy (New York: Simon and Schuster, 2013); Parisa Hafezi, Louis Charbonneau, John Irish and Arshad Mohammed, "Iran Deal Reached, Obama hails step towards 'more hopeful world," Reuters, July 15, 2015, http:// www.reuters.com/article/2015/07/15/us-iran-nuclear-idUSKCNOPMOCE20150715. 
23. “Great sacrifices, small rewards”, The Economist, January $1^{\text {st }} 2011,18$.

24. Gary Sick, "The United States in the Persian Gulf. From Twin Pillars to Dual Containment", in David M. Lesch, ed., The Middle East and the United States. A Historical and Political Reassessment (Boulder, CO: Westview Press, 2003), 291-307.

25. Douglas Little, "The Cold War in the Middle East: Suez crisis to Camp David Accords," in Melvin P. Leffler and Odd Arne Westad (eds.) The Cambridge History of the Cold War, Vol. II, Crises and Détente (Cambridge: Cambridge University Press, 2010), 305-326; Peter Sluglett, "The Cold War in the Middle East," in Louise Fawcett, ed., International Relations of the Middle East (Oxford: Oxford University Press, 2013), 65-66.

26. Olav Njolstad, "Shifting Priorities: The Persian Gulf in US Strategic Planning in the Carter Years", Cold War History 4, No. 3, (April 2004): 21-55; Kapstein, Insecure Alliance, 193.

27. William E. Odom, "The Cold War Origins of the US Central Command", Journal of Cold War Studies 8, No. 2 (Spring 2006): 59-64; Palmer, Guardians, 112-117.

28. John Gerard Ruggie, "Third Try at World Order? America and Multilateralism After the Cold War", Political Science Quarterly 4 (Autumn 1994): 553-570; G. John Ikenberry, After Victory. Institutions, Strategic Restraint, and the Rebuilding of Order After Major Wars (Princeton: Princeton University Press, 2001), 214-255; Colin Dueck, Reluctant Crusaders. Power, Culture, and Change in American Grand Strategy (Princeton: Princeton University Press, 2006).

29. Charles Krauthammer, “The Unipolar Moment”, Foreign Affairs, 70 (Winter 1990-1991): 22-33. 30. Michael Mastanduno, "Preserving the Unipolar Moment: Realist Theories and U.S. Grand Strategy after the Cold War", International Security 21, No. 4 (Spring 1997): 49-88.

31. Andrew J. Bacevich, The New American Militarism. How Americans Are Seduced by War [Updated Edition] (Oxford and New York: Oxford University Press, 2013), 14.

32. Bacevich, Militarism, passim; P. Edward Haley, Strategies of Dominance. The Misdirection of U.S. Foreign Policy (Baltimore: Johns Hopkins University Press, 2006).

33. F. Gregory Gause III, "The International Politics of the Gulf," in Fawcett ed., International Relations, 296.

34. "The decline of deterrence," The Economist, May $3^{\text {rd }}, 2014$. For a study of Obama's foreign policy emphasizing the president's quest for a new US role in the world, see: James Mann, The Obmians. The Struggle Inside the White House to Redefine American Power (New York: Penguin, 2012). For an alternative explanation, emphasizing continuity with previous administrations, see: Fawaz A. Gerges, Obama and the Middle East. The End of America's Moment? (Houndmills, Basingstoke: Palgrave Macmillan, 2012)

35. Mann, Obamians, XIX.

36. Michael A. Cohen, “Obama's Understated Foreign Policy Gains," The New York Times, July 9, 2014, http://www.nytimes.com/2014/07/10/opinion/obamas-understated-foreign-policygains.html?partner=rss\&emc=rss ; Michael O'Hanlon, "The Obama Defense," Foreign Affairs, May 28, 2014, http://www.foreignaffairs.com/articles/141473/michael-ohanlon/the-obama-defense . 37. Mann, Obamians, 340.

38. Mann, Obmians; Hastings, "War Room;" Jo Becker and Scott Shane, "Secret 'Kill List' Proves a Test for Obama's Principles and Will," The New York Times, May 29, 2012, http:// www.nytimes.com/2012/05/29/world/obamas-leadership-in-war-on-al-qaeda.html? pagewanted=all\&_r=0 .

39. Thomas L. Friedman, "Iran and the Obama Doctrine," The New York Times, April 5, 2015, http://www.nytimes.com/2015/04/06/opinion/thomas-friedman-the-obama-doctrine-and-iraninterview.html ; Ann-Marie Slaughter, "Leading by Engaging," Project Syndicate, April 24, 2015, http://www.project-syndicate.org/commentary/obama-foreign-policy-record-by-anne-marieslaughter-2015-04.

40. Gause, Persian Gulf, 3-6. 
41. Mahmoud A. El-Gamal and Amy Myers Jaffe, Oil, Dollars, Debt, and Crises. The Global Curse of Black Gold (Cambridge: Cambridge University Press, 2010), 14-16, 44-50; Adelman, Genie, 122-124; Gause, Persian Gulf, 8-9; Pollack, Unthinkable, 89.

42. Richard Nixon: "Address to the Nation on the War in Vietnam," November 3, 1969, Peters and Woolley, The American Presidency Project. http://www.presidency.ucsb.edu/ws/?pid=2303 .

43. Gause, Persian Gulf , 25-34. It seems important to observe that the policy of propping up the Gulf's rising powers had an important economic side effect: the sale of weapons would improve the US trade balance by increasing exports toward those countries which were reaping the highest benefits from the increase in oil prices - a scheme known as the petrodollar recycling. ElGamal and Jaffe, Oil, 121-122.

44. Yergin, Prize, 432-460; Ray Takeyh, Hidden Iran. Paradox and Power in the Islamic Republic (New York: Holt, 2006), 85-95; As observed by Kenneth Pollack, if the CIA-orchestrated coup that toppled the Mossadegh Government in August 1953 "was the defining moment of the U.S.-Iranian relationship for Iranians, the 1979-81 hostage crisis was the defining moment of the relationship for Americans." Kenneth Pollack, The Persian Puzzle. The Conflict between Iran and America (New York: Random House, 2004), 172.

45. Pollack, Persian Puzzle, 182-188.

46. Robert J. Lieber, "Oil and Power after the Gulf War", International Security 17, No. 1 (Summer 1992): 161-162, 166-167; Robert Mabro, "The impact of the Gulf crisis on world oil and OPEC", International Journal 49, No. 2 (Spring 1994): 244; George Bush and Brent Scowcroft, A World Transformed (New York: Knopf, 1998), 322-323.

47. Bush and Scowcroft, World, 399-400; Colin Powell with Joseph E. Persico, My American Journey (New York: Ballantine Books, 1996), 478

48. Richard N. Haass, War of Necessity, War of Choice. A Memoir of Two Iraq Wars (New York: Simon and Shuster, 2009), 129-131. Norman H. Schwarzkopf with Peter Petre, It Doesn't Take a Hero (New York: Bantam Books, 1992), 543-544; James A. Baker III with Thomas De Frank, The Politics of Diplomacy. Revolutions, War and Peace 1989-1992 (New York: Putnam's, 1995), 410.

49. Baker, The Politics of Diplomacy, 438-442; "Remarks to the American Association for the Advancement of Science", February 15, 1991, Public Papers of President George H.W. Bush, http:// bushlibrary.tamu.edu/research/public_papers.php?id=2709\&year=1991\&month=2 .

50. Gideon Rose, How Wars End. Why We always Fight the Last Battle (New York: Simon and Shuster, 2010), 218. Bush and Scowcroft, World, 433.

51. "The President's News Conference on the Persian Gulf Conflict", March 1, 1991, Public Papers of the Presidents: George H.W. Bush, http://bushlibrary.tamu.edu/research/public_papers.php? $\underline{\mathrm{id}=2755 \& \text { year }=1991 \& \text { month }=3}$.

52. Speech Featuring Martin Indyk, “The Clinton Administration's Approach to the Middle East”, Soref Symposium 1993, http://www.washingtoninstitute.org/print.php?template=C07\&CID=61; Anthony Lake, “Confronting Backlash States”, Foreign Affairs 73, No. 2 (Mar.-Apr. 1994): 45-55.

53. Javier Perez De Cuellar, Pilgrimage for Peace: a Secretary General's Memoir (New York: St. Martin's Press, 1997), 177-178.

54. Torbat, "Glance," 86-87; Takeyh, Hidden Iran, 110-116; Pollack, Persian Puzzle, 265-277, 286-289. 55. John Ikenberry, "American Grand Strategy in the Age of Terror", Survival 43, No. 4 (Winter 2001-02): 19-34; Elizabeth Borgwardt, A New Deal for the World. America's Vision for Human Rights (Cambridge: Harvard University Press, 2005), 11; Christian Alfonsi, Circle in the Sand. The Bush Dynasty in Iraq (New York: Vintage, 2007), 384-385; Packer, Assassins' Gate, 385-395.

56. Ahmed Rashid, “The Taliban: Exporting Extremism”, Foreign Affairs 78, No. 6 (Nov-Dec. 1999): 22-35; Takeyh, Hidden Iran, 117-134.

57. Ironically, as revealed by interrogations conducted on Saddam Hussein in the aftermath of his capture by American forces, the Iraqi dictator's refusal to release full evidence of the dismantlement of Iraq's WMD program was due to his desire to maintain a certain degree of 
ambiguity in order to deter more effectively an Iranian attack. In other words, by 2002-2203 Saddam Hussein was doing his best to make Iraq a bulwark against Iran, as wished by the architects of the first Gulf War. National Security Archive, "Saddam Hussein Talks to the FBI", Casual Conversation, June 11, 2004, http://www.gwu.edu/ nsarchiv/NSAEBB/ NSAEBB279/24.pdf.

58. Vali Nasr, The Shia Revival. How Conflict Within Islam Will Shape the Future (New York: Norton, 2006), 185-226. The Iranian government officially maintains that its nuclear program is peaceful. Evidence collected by the US and Western intelligence communities strongly suggest, however, that the Tehran regime has explored weaponization options. Pollack, Unthinkable, 39, 51-52; Mohammad Javad Zarif, "Iran is committed to a peaceful nuclear program," TheWashington Post, June 13, 2014, http://www.washingtonpost.com/opinions/mohammad-javad-zarifiran-is-committed-to-apeaceful-nuclear-program/2014/06/13/491fc982-f197-11e3-

bf76-447a5df6411f_story.html .

59. Thomas E. Ricks, The Gamble. General Pretraeus and the American Military Adventure in Iraq (New York: Penguin Books, 2010), 327-334.

60. Greg Muttitt, Fuel on the Fire. Oil and Politics in Occupied Iraq (London: Vintage, 2012); Yergin, Quest, 160.

61. Yergin, Quest, 298-311; El-Gamal and Jaffe, Oil, 95-96.

62. Joseph Logan, “Last U.S. Troops leave Iraq, ending war", Reuters, December 18, 2011, http:// www.reuters.com/article/2011/12/18/us-iraq-withdrawal-idUSTRE7BH03320111218; Thomas E. Ricks, Fiasco. The American Military Adventure in Iraq (New York: Penguin, 2007). By the time these pages are written, Iraq is in fact in the midst of a new spiral of violence and conflict. "Two Arab countries fall apart," The Economist, June 14 $14^{\text {th }}, 2014$, http://www.economist.com/news/ middle-east-and-africa/21604230-extreme-islamist-groupseeks-create-caliphateand-spread-jihad-across?fsrc $=\mathrm{scn} / \mathrm{fb} / \mathrm{te} / \mathrm{bl} / \mathrm{ed} /$ twoarabcountriesfallapart .

63. Marc Lynch, The Arab Uprising. The Unfinished Revolutions of the New Middle East (New York: Public Affairs, 2013); Augustus Richard Norton, "The Puzzle of Political Reform in the Middle East," in Fawcett, ed., International Relations, 127-147; Bassem Awadallah and Adeel Malik, "The Economics of the Arab Spring," Huffington Post, January 10, 2012, http:// www.huffingtonpost.com/bassem-awadallah/the-economics-of-the-arab_b_1196473.html ; Béligh Nabli, Comprendre le monde arabe (Paris: Armand Colin, 2013), 223-246; Daron Acemoglu and James A. Robinson, Why Nations Fail. The Origins of Power, Prosperity and Poverty (New York: Crown Business, 2012), pp. 1-5;

64. "Arab Spring: 10 unpredicted outcomes," BBC News, December 13, 2013, http:// www.bbc.com/news/world-middle-east-25212247 . In fact, in the early stages of the "Arab Spring," the risk of instability in the oil producing Persian Gulf monarchies was a cause of concern among analysts. Nouriel Roubini, "The Economic consequences of the Arab Revolts," Project Syndicate, March 14, 2011, http://www.project-syndicate.org/commentary/the-economicconsequences-of-the-arab-revolt ; Ed Morse, "The new geopolitics of oil," Financial Times, April 6, 2011, $\quad$ http://www.ft.com/intl/cms/s/0/fea9cfb0-6044-11e0abba-00144feab49a,s01=1.html\#axzz1SP7vhHNq .

65. Kenneth M. Pollack and Ray Takeyh, "Near Eastern Promises," Foreign Affairs, May/June2014, http://www.foreignaffairs.com/articles/141213/kenneth-m-pollack-and-ray-takeyh/neareastern-promises .

66. Asjylin Loder, "American Oil Growing Most Since First Well Signals Independence," Bloomberg, December 18, 2012, http://www.bloomberg.com/news/2012-12-19/american-oil-most-sincefirst-well-in-1859-signals-independence.html ; "Energy to spare," The Economist, November 17, 2012, 64 .

67. Aviezer Tucker, "The New Power Map," Foreign Affairs, January 9, 2013, http:// www.foreignaffairs.com/articles/138597/aviezer-tucker/the-new-power-map ; Ian Bremmer and 
Kenneth A. Hersh, "When America Stops Importing Energy," The New York Times, May 22, 2013, http://www.nytimes.com/2013/05/23/opinion/global/when-america-stops-importingenergy.html?ref=global\&_r=1\&

68. Robert Bryce, "Forty Years After OPEC Embargo, U.S. Is Energy Giant," Bloomberg, October 10, 2013, http://www.bloomberg.com/news/2013-10-10/forty-years-after-opec-embargo-u-s-isenergy-giant.html . As noted by Peter Coy in early 2014: "Want to know how the U.S. managed to narrow its trade deficit to the smallest figure in four years? Look no further than Texas, North Dakota, and other states where oil production is booming." Peter Coy, "How the Booming Oil Patch Helps U.S. Trade," BloombergBusinessweek, January 7, 2014, http://www.businessweek.com/ articles/2014-01-07/how-the-booming-oil-patch-helps-u-dot-s-dot-trade . Also see: Ryan McCarthy, The improving state of U.S. trade," Reuters, January 7, 2014, http://blogs.reuters.com/ data-dive/2014/01/07/the-improving-state-of-us-trade/ ; Also see: Michael Levi, The Power Surge. Energy, Opportunity, and the Battle for America's Future (Oxford: Oxford University Press, 2013), 75-76.

69. As pointed out by M. A. Adelman, "Higher output helps consumers and lower output hurts them, no matter where the oil is from or where it goes." M.A. Adelman, "The Real Oil Problem", Regulation, (Spring 2004), 19. Also see: Levi, Power Surge, 65.

70. From a short-term perspective, it is important to note that an increased global supply of oil has favored the enforcement of the US-led sanctions policy toward Iran. Indira A.R. Lakshmanan and Asjylyn Loder, "Iran Loses Nuclear Leverage as World Ingores Export Drop," Bloomberg, November 7, 2013, http://www.bloomberg.com/news/2013-11-07/iran-loses-nuclear-leverageas-world-ignores-export-drop.html.

71. Yergin, Quest, 277-279; Michael A. Levi, “The False Promise of Energy Independence," The New York Times, December 21, 2012, http://www.nytimes.com/2012/12/21/opinion/the-falsepromise-of-energy-independence.html?_r=1\&.

72. Giacomo Luciani, "Oil and Political Economy in the International Relations of the Middle East," in Fawcett, ed., International Relations, 104; Daniel Yergin, "The Global Impact of U.S. Shale," Project Syndicate, January 8, 2014, http://www.project-syndicate.org/commentary/daniel-yergintraces-the-effects-of-america-s-shale-energy-revolution-on-the-balance-of-global-economicand-political-power.

73. "The masochism tango," The Economist, December 15, 2012, 34-35, http:// www.economist.com/news/middle-east-and-africa/21568391-president-barack-obama-wouldavoid-entanglement-middle-east-he/ ; Pollack and Takeyh, "Near Eastern;" "Oil market spike on Iraq concerns," BBC News, June 13, 2014, http://www.bbc.com/news/business-27836376 .

74. El-Gamal and Jaffe, Oil, 90.

75. "Parameters for a Joint Plan of Action Regarding the Islamic Republic of Iran's Nuclear Program," The White House - Office of the Press Secretary, April 2, 2015, https:// www.whitehouse.gov/the-press-office/2015/04/02/parameters-joint-comprehensive-planaction-regarding-islamic-republic-ir ; Jeffrey Lewis, "It's a Damn Good Deal," Foreign Policy, July 14, 2015, http://foreignpolicy.com/2015/07/14/its-a-damn-good-deal-iran-nuclear-agreementjoint-comprehensive-plan-of-action/.

76. Kenneth N. Waltz, The Spread of Nuclear Weapons: More May Be Better (London: IISS Adelphi Papers, 1981); Scott D. Sagan, "Why Do States Build Nuclear Weapons?," International Security 21, No. 3 (Winter, 1996-1997): 54-86.

77. Elizabeth Drew, "How They Failed to Block the Iran Deal," The New York Review of Books, October 22, 2015, http://www.nybooks.com/articles/archives/2015/oct/22/how-they-failedblock-iran-deal/ ; "Iran's Arab neighbors want assurances nuclear deal not against them," Reuters, November 28, 2013, http://www.reuters.com/article/2013/11/28/us-iran-nuclear-gulfidUSBRE9AR0GS20131128; Mohammed Bin Nawaf Bin Abdulaziz Al Saud, "Saudi Arabia will go it alone," The New York Times, December 17, 2013, http://www.nytimes.com/2013/12/18/opinion/ 
saudi-arabia-will-go-it-alone.html?partner=rss\&emc=rss ; "A big gap to close," The Economist, January 18, 2014, http://www.economist.com/news/middle-east-and-africa/21594314-somesupporters-iran-deal-doubt-there-will-be-long-term-pact-big-gap ; Fredrik Dahl and Louis Charbonneau, "West still struggles to cut feared bomb risk in Iran nuclear talks," Reuters, July 21, 2014, http://www.reuters.com/article/2014/07/21/us-iran-nuclear-talksidUSKBNOFQ18S20140721.

78. Zahra Hosseinian, "Iranians count on president-elect Rohani to bring change," Reuters, June 16, 2013, http://www.reuters.com/article/2013/06/16/us-iran-electionidUSBRE95C1E120130616 ; Mohammad Javad Zarif, "What Iran Really Wants," Foreign Affairs, May/June 2014, http://www.foreignaffairs.com/articles/141209/mohammad-javad-zarif/whatiran-really-wants .

79. Kenneth Pollack, "Tehran and Washington: Unlikely Allies In An Unstable Iraq," Brookings, June 3, 2013, http://www.brookings.edu/blogs/iran-at-saban/posts/2013/06/31-iraq-iranpollack; Philip Robins, "The War for Regime Change in Iraq," in Fawcett, ed., International Relations, 316; Yergin, Quest, 59-61; Philippe Sébille-Lopez, Géopolitiques du pétrole (Paris: Armand Colin, 2006), 194-196.

80. El-Gamal and Jaffe, Oil, 150-153; Yergin, Quest, 224-225, 281-284; John B. Alterman, "China's Balancing Act in the Gulf," CSIS Gulf Analysis Paper, August 2013, https://csis.org/files/ publication/130821_Alterman_ChinaGulf_Web.pdf ; Damien Ma, "Dependence on Middle Eastern Oil: Now It's China's Problem, Too," The Atlantic, July 19, 2012, http://www.theatlantic.com/ international/archive/2012/07/dependence-on-middle-eastern-oil-now-its-chinas-problem-too/ 259947/

81. Obama administration officials appear to have explicitly mentioned this kind of reasoning with their Chinese counterparts. Mann, Obamians, 205.

\section{ABSTRACTS}

Both as a superpower and as the West's leading security provider, the US has seen its commitment to the stability of the Gulf region and the preservation of access to its oil supplies increase. US Persian Gulf policy, however, has been shaped not only by pure geopolitical considerations, but also by ideological factors concerning America's status and role in international relations. Until recently, US policy toward the Persian Gulf was distorted by the appeal of America's unchallenged military primacy. Confronted with the contradictions and dilemmas of promoting ideals and protecting the national interest, US policy-makers demonstrated a remarkable penchant for instituting policies that overestimated the potential of America's military power as a tool for creating new political realities and favorable outcomes in the region. Such an approach has proved to be extremely costly and frustrating, while the time seems ripe to explore new strategies. The US should not strive to reshape or control the geopolitics of the Gulf, as both these approaches are unfeasible. The idea of disengagement from the region, moreover, appears delusional even when the implications of the unconventional energy revolution are held into account. Rather, America and its allies should focus their engagement on protecting their interests without becoming part of the region's sources of instability. 
INDEX

Keywords: energy security, geopolitics, ideology, Middle East, oil, Persian Gulf, United States, US foreign policy, US military power

\section{AUTHOR}

\section{DIEGO PAGLIARULO}

Independent scholar 